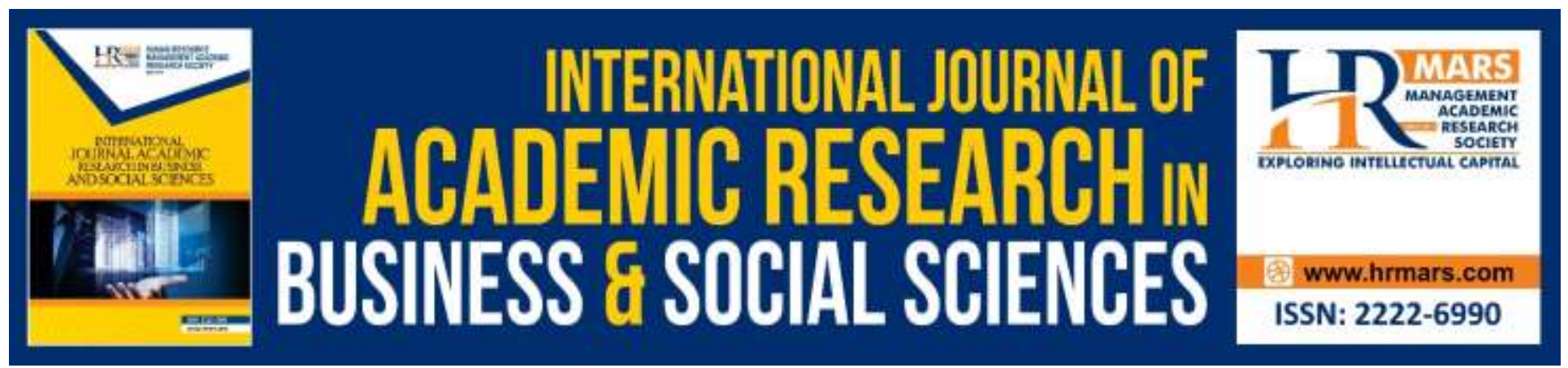

\title{
Impact of Trade Creation and Trade Diversion in ASEAN- Japan Comprehensive Economic Partnership (AJCEP)
}

Gayatri Talita Aprilia, Rossanto Dwi Handoyo, Abdul Rahim Ridzuan, Mohamad Idham Md Razak

To Link this Article: http://dx.doi.org/10.6007/IJARBSS/v10-i5/7208

DOI:10.6007/IJARBSS/v10-i5/7208

Received: 09 March 2020, Revised: 12 April 2020, Accepted: 29 April 2020

Published Online: 15 May 2020

In-Text Citation: (Aprilia et al., 2020)

To Cite this Article: Aprilia, G. T., Handoyo, R. D., Ridzuan, A. R., \& Razak, M. I. M. (2020). Impact of Trade Creation and Trade Diversion in ASEAN-Japan Comprehensive Economic Partnership (AJCEP). International Journal of Academic Research in Business and Social Sciences, 10(5), 372-380.

Copyright: (c) 2020 The Author(s)

Published by Human Resource Management Academic Research Society (www.hrmars.com)

This article is published under the Creative Commons Attribution (CC BY 4.0) license. Anyone may reproduce, distribute, translate and create derivative works of this article (for both commercial and non-commercial purposes), subject to full attribution to the original publication and authors. The full terms of this license may be seen at: http://creativecommons.org/licences/by/4.0/legalcode

Vol. 10, No. 5, 2020, Pg. 372 - 380

http://hrmars.com/index.php/pages/detail/IJARBSS

JOURNAL HOMEPAGE

Full Terms \& Conditions of access and use can be found at http://hrmars.com/index.php/pages/detail/publication-ethics 


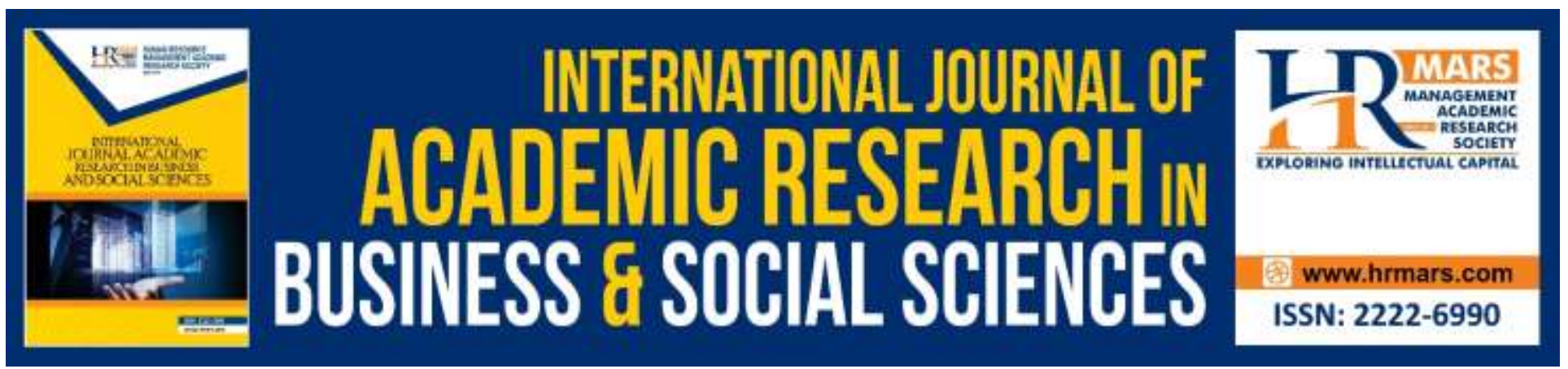

\section{Impact of Trade Creation and Trade Diversion in ASEAN-Japan Comprehensive Economic Partnership (AJCEP)}

Gayatri Talita Aprilia, Rossanto Dwi Handoyo

Faculty of Economics and Business, Universitas Airlangga

Email: gayatri.talita-13@feb.unair.ac.id, Rossanto_dh@feb.unair.ac.id

Abdul Rahim Ridzuan, Mohamad Idham Md Razak

Faculty of Business and Management, Universiti Teknologi MARA, Melaka Campus, Malaysia

Email: Rahim670@staf.uitm.edu.my, iedham@warga.uitm.edu.my

\section{Abstract}

This study uses a gravity model to analyze the impact of the ASEAN-Japan Comprehensive Economic Partnership (AJCEP) agreement on total Indonesian exports and to analyze the occurrence of trade creation or trade diversion. The data used in this study is panel data, and the period chosen for this study is from the year 2000 to 2015, consisting of 16 countries. The result finds that the coefficient value of the FTA dummy is 0.207 . This positive relationship indicates that there is a trade creation in AJCEP member countries and non AJCEP members. Therefore, it indicates that the welfare of member states and non AJCEP members. Total GDP, the real exchange rate is positively correlated, and GDP per capita difference and distance are negatively related to total Indonesian exports.

Keywords: ASEAN-Japan Comprehensive Economic Partnership, Gravity Model, Trade Creation, and Trade Diversion.

\section{Introduction}

The development of international trade leads to more free trade in the form of cooperation, namely bilateral, regional, and multilateral cooperation. International trade agreements aim to reduce or eliminate trade barriers. Trade liberalization in a country with a pattern of international cooperation has a positive impact on economic growth in a country. The value of world trade will grow larger than the real world gross domestic product (GDP) growth (Krueger, 1999).

One of the indicators to measure the impact of international trade cooperation are trade creation and trade diversion. Trade creation occurs when some domestically produced products are replaced by imported products with relatively cheaper production costs, and this activity will improve the welfare of member countries because it encourages greater production specialization based on comparative advantage (Salvatore, 2014: 312). Trade diversion occurs when the imported goods 
INTERNATIONAL JOURNAL OF ACADEMIC RESEARCH IN BUSINESS AND SOCIAL SCIENCES Vol. 10, No. 5, May, 2020, E-ISSN: 2222-6990 ㄷ 2020 HRMARS

produced at a lower cost than the goods made by the outside union or non-member are replaced by imported goods at a higher cost than the member countries. Thus, this will reduce welfare (Salvatore, 2014: 314). This transfer will result in additional costs and can reduce a country's income.

The formation of FTA will increase trade in goods and services among participating members and increase employment opportunities in these countries. Besides improving welfare, Lindert and Kindleberger (1986) argue that free trade will increase the quantity of world trade and efficiency. Urata and Kiyota (2003) point out that FTA in East Asia will have a positive influence on economic growth. On the other hand, according to Haryadi et al. (2008), trade liberalization which practice removal of trade barriers has an impact on the decline between Indonesia's Gross Domestic Product (GDP) and Australia-New Zealand's GDP.

Based on Newton's Gravity Law, the gravity model equation can explain the trade volume between two countries is positively related to real GDP (market share production) and negatively related to the distance between countries due to high transportation costs, thus increasing production costs. Various studies from Beers (2000), Kien (2009), Yang and Martinez (2014) have proven that the gravity model can explain the flow of trade between two countries by showing the law of gravity. The gravity model can explain the flow of trade, which is influenced by GDP and the distance between the two countries, and distance is a trade barrier that affects trading volume. The farther distance between the two trading countries, the greater the transportation costs will incur. Conversely, if the distance between the trading countries is closer, the smaller the transportation costs will incur.

Based on the background above, the research gap from this study is the trade agreement in the form of trade creation or trade diversion from the Indonesian export side in the AJCEP agreement and differences in export performance in AJCEP member countries and non-AJCEP members. The benefit of this research is to observe the profit or loss in the participation of AJCEP member countries on the export side. Therefore, this study attempts to estimate the impact of trade creation or trade diversion on Indonesia with Japan and ASEAN on the export side. The results of this study are expected to find out whether there is an effect of trade creation or trade diversion from the collaboration of AJCEP.

\section{Literature Review \\ Trade Creation dan Trade diversion}

The formation of FTAs is made to reduce trade barriers in the form of reducing or eliminating tariffs and non-tariffs. This effort will increase the value of a country's trade by increasing trade in the form of trade creation and trade diversion. Viner (1950) was the first party to spark the concept of trade creation and trade diversion. In trade creation, when some domestic commodities products or products that are imported from non-member countries with high costs are replaced by commodities produced from fellow members of the agreement at a lower cost to increase welfare (Salvatore, 1996).

Trade diversion occurs when a free trade agreement causes an increase in product imports from member countries to replace imported products from non-member countries that are offered at lower prices (Krugman, 2012: 277). This occurs because of the enactment of agreements for fellow member states (tariffs are abolished), which results in the products from non-member countries that were previously cheaper to become more expensive because they still have to bear the tariffs cost. Meanwhile, the products from the member countries that are less efficient will become relatively 
cheap because they no longer pay tariffs. This trade diversion tends to reduce welfare because it shifts production activities from more efficient producers from non-member countries to nonefficient producers from fellow members. Thus, the existence of trade diversion (Trade Diversion) will exacerbate the allocation of international resources and distance production activities from a comparative advantage (Salvatore, 1996: 387).

Trade creation and trade diversion come from members of an agreement. Both will change the pattern and volume of trade in place, either in increasing or decreasing trend. The welfare of nonmembers foreign countries in the short term will most be likely in the reduction of the utilization of factors of production. The economy among the non-member is expected to reduce because the export market is reduced, and overall, it will become less efficient. If more members in the agreement bring about the creation of trade (Trade Creation), then those who will benefit in the form of increased welfare are not only member states but also non-member countries. Conversely, if what happens is the transfer of trade (Trade Diversion), then the member countries will get a loss, but nonmember countries will certainly get a loss (Salvatore, 1996: 387).

\section{Gravity Model}

The gravity model is a bilateral trade between two countries that has a positive correlation with GDP (Gross Domestic Product) of the two countries and will be smaller as the distance separates the two countries. The bigger and closer the two countries are, the greater the volume of trade will happen between the two countries. (Salvatore, 2014: 7). The gravity model is used to analyze the pattern of bilateral trade flows between countries in a particular region as a function of the economic period of each country, the distance between countries, and other factors. Gravity models are now often used as a method that can evaluate the trading potential of a product or service between countries, and it can be used to see how large an area is. The background of the formation of this model is richer countries will trade more broadly, as compared to poorer countries. The richer country will not consider the gap between the distance as an obstacle. The basic equation used to estimate the gravity-based model (Starck CS, 2012) is as follows:

Tij=A $\times$ Yi $\times$ yj/Dij......

Which:

$T_{-}$ij $=$Value of trade between country $\mathrm{i}$ and country $\mathrm{j}$

$Y_{-} i=$ GDP of country $i$

$Y j=$ GDP of country $j$

$A=$ Constant

D_ij = Distance between two countries

This model has been proven as empirically strong by econometric analysis, and it is known to be highly consistent in explaining various phenomena such as migration, tourism, and trade flows of goods (Bergstand, 1985), and other factors such as income levels, diplomatic relations, and trade policies are also included in this model. Kien (2009), Caporale et al. (2011), and Yang \& Inmaculada (2014) agree that the effect of a free trade agreement on trade flow can be estimated using the gravity model.

Kien's research (2009) examines the impact of trade creation and trade diversion which uses the gravity model to estimate trade from 39 countries with 26 members from 4 kinds of agreements, namely, Europan Union (EU), ASEAN Free Trade Area (AFTA), North American Free Trade Agreement (NAFTA) and MERCOSUR or the Common Market of the South in the period 1988-2002 based on the 
INTERNATIONAL JOURNAL OF ACADEMIC RESEARCH IN BUSINESS AND SOCIAL SCIENCES Vol. 10, No. 5, May, 2020, E-ISSN: 2222-6990 @ 2020 HRMARS

form of a two-way error component of the gravity model. The estimate shows that export flows are increasing proportionally to GDP, and the formation of AFTA has resulted in significant trade creation among its members.

The method used is Hausman-Taylor (HT). In this method shows that distance is a more important obstacle in export flows. In general, free trade areas do not have the same impact on each regional trade grouping. The securities that are against the AFTA and the EU, which trade creations appear in all areas of free trade but differ in the EU agreement. In the EU agreement shows the trade diversion results on the import side while AFTA shows the effect of trade creation on the export side. Distance has a negative impact on export flows and the formation of free trade areas. The impact proved that transportation costs were greater than tariffs, and this was a major obstacle to trade flows. Trade facility policy is an important role in establishing the AFTA transition stage in free trade areas.

Yang and Inmaculda's (2014) study, in their research using aggregate data and disaggregated data in four categories: raw agricultural products, manufactured products, chemical products, and machinery, and transportation equipment traded by 31 countries and covering the period from 19952010. According to the estimation results of using aggregate data, the agreement between ASEAN and China produces a positive trading effect. These results are positive and significant by reducing and eliminating barriers to tariffs at ACFTA will increase the total trading volume in intra-block member countries but also between extra-blocks. The ACFTA effect is estimated for the export of manufactured goods and the chemical products of significant trade creation and trade diversion effects for agricultural raw materials, as well as machinery and transportation equipment.

\section{Model Analysis}

$$
\begin{aligned}
\log X_{i j t} & =\beta_{0}+\beta_{1} \log G D P_{i j t}+\beta_{2} \log D G D P C_{i j t}+\beta_{3} \log D i s t_{i j}+\beta_{4} \log E R_{j t} \\
& +\beta_{5} D F T A_{i j t}+\varepsilon_{i j t}
\end{aligned}
$$

\section{Research Method}

\section{Definition of Operational Variables}

1. Total Export $\left(X_{i j t}\right)$

The gravity model, in general, is to use total exports as the dependent variable. In this research, aggregate trade data will be used. The value of Indonesia's total trade with ASEAN countries, Japan, and some trading partners is calculated entirely in United States Dollar (US \$) units. This data is then converted into natural logarithms.

2. Total Gross Domestic Product $\left(G D P_{i j t}\right)$

GDP is used as a proxy for the size of the economy in a country. Countries with large GDP tend to have high domestic production so that it becomes the right measure to assess export performance in a country. In this study, the GDP used is the GDP constant with the 2010 base year in US \$ units. The total GDP consists of exporting countries and importing countries. This GDP data is then converted into natural logarithms.

3. Gross Domestic Product Per Capita Difference or Difference $\left(D G D P C_{i j t}\right)$

This is the difference or difference in per capita income between Indonesia and its trading partner countries. On the demand side, differences in per capita income are used to 
INTERNATIONAL JOURNAL OF ACADEMIC RESEARCH IN BUSINESS AND SOCIAL SCIENCES

Vol. 10, No. 5, May, 2020, E-ISSN: 2222-6990 @ 2020 HRMARS

see consumption patterns. The DGCA variable is calculated from the difference in total GDP per capita between Indonesia and one of its trading partner countries, then converted into logarithmic form. The data in this study uses GDP per capita constant with the 2010 base year. The difference or difference in GDP per capita data is then converted into natural logarithms.

4. Distance between countries ( Dist $_{i j}$ )

The distance between countries used in this study is the distance between the capital (economic center) of the country of Indonesia and members and non-members of AJCEP. Geographic distance is used as a proxy for transportation and communication costs. The distance used is to use kilometer units, the greater the distance between countries, the more expensive the transportation costs incurred. The distance data between countries is then converted into natural logarithms.

5. Exchange Rate $\left(E R_{i}\right)$

The exchange rate is the relative price of goods between the two countries. Real exchange rates state the level at which a country can trade goods for goods from other countries (Mankiw, 2007). Exchange rates play a role in spending decisions because they allow changing the price of different countries into the same terms. Depreciation of the country's currency against foreign currencies makes exports cheaper and imports more expensive. Conversely, when appreciating the currency makes exports more expensive, and imports are much cheaper (Krugman, 2012: 376). This exchange rate data is then converted into natural logarithms. 6. Dummy FTA (DFTA_ijt) Dummy variables for intra regions indicate the effects of trade creation or trade diversion. The dummy variable will be worth one since 2008 if the country of origin and export destination is a member of AJCEP that trades in the region and has zero value for the destination country of export is a non-member of AJCEP.

6. Dummy FTA $\left(D F T A_{i j t}\right)$

Dummy variables for intra regions indicate the effects of trade creation or trade diversion. The dummy variable will be worth one since 2008 if the country of origin and export destination is a member of AJCEP that trades in the region and has zero value if the destination country of export is a non-member of AJCEP.

\section{Results and Discussion}

The analysis of the Random Effect model was used in this research after confirming its suitability through the Haussman test. The outcome is displayed in Table 1 below: 
INTERNATIONAL JOURNAL OF ACADEMIC RESEARCH IN BUSINESS AND SOCIAL SCIENCES Vol. 10, No. 5, May, 2020, E-ISSN: 2222-6990 ㄷ 2020 HRMARS

Table 1.

Random Effect Regression Results

\begin{tabular}{|c|c|c|c|}
\hline \multirow[t]{2}{*}{ Variable } & $\begin{array}{l}\text { Regression } \\
\text { Coefficient }\end{array}$ & \multirow[t]{2}{*}{ Coefficient } & \multirow[t]{2}{*}{ Conclusion } \\
\hline & Unstandardized & & \\
\hline Constants & -32.3291 & $0,000 *$ & - \\
\hline GDPij & 2.3127 & $0,000 *$ & Significant \\
\hline DGDPCij & -0.1233 & $0,074^{*}$ & Significant \\
\hline ERij & 0.0505 & $0,078 *$ & Significant \\
\hline DISTCij & -1.307 & $0,091^{*}$ & Significant \\
\hline DFTAij & 0.2071 & $0,000 *$ & Significant \\
\hline$R^{2}$ & 0.4567 & & \\
\hline \multicolumn{4}{|c|}{ Dependent Variable: X_ijt } \\
\hline
\end{tabular}

\section{Effect of GDP Total on Indonesia's Total Exports}

The total GDP (GDPij) variable represents the economic size of Indonesian exports with AJCEP member countries and non-AJCEP members. Based on the statistical estimation results of this study is that the total GDP variable is significant and influential on Indonesian exports. GDP and exports have a positive relationship. Increased income and demand for output in a country will encourage increased demand for goods and services. Therefore, by increasing GDP in a country, it tends to increase the amount of exports produced in that country.

\section{Effect of Difference in GDP Per Capita on Indonesia's Total Exports}

Variable differences or differences in income per capita (DGDPCij) between two trading partners are statistically significant and affect the total exports of Indonesia with AJCEP member countries and non-AJCEP countries. It is generally found that consumption patterns can explain the flow in Indonesia's export trade. Research from Elliot and Ikemoto (2004), is in line with the results of this study by including differences or differences in per capita income. Countries with greater differences or differences in income tend to have relatively small export levels. Differences or differences in GDP per capita capture the extent to which trading partner countries demand goods that tend to be similar but different. The demand is measured by the population. Exports tend to increase if these countries have a similar level of difference or difference in GDP per capita.

\section{Effect of Exchange Rates on Indonesia's Total Exports}

The exchange rate variable (ERj) has a positive and significant relationship to Indonesia's total exports in the period 2000-2015. Positive coefficient values indicate that the exchange rate is high, or the strengthening of the domestic currency is that which is relative to the trading partner country against Indonesia, which indicates that the low price of Indonesia's relative products. This condition encourages domestic residents or trading partners to buy more imported goods, and overseas communities buy less domestic goods. This is in agreement with Kien's research (2009), which states that there is a positive and significant relationship between exchange rates and trading volume. 
INTERNATIONAL JOURNAL OF ACADEMIC RESEARCH IN BUSINESS AND SOCIAL SCIENCES

Vol. 10, No. 5, May, 2020, E-ISSN: 2222-6990 ㄷ 2020 HRMARS

\section{The influence of inter-country distance on total Indonesian exports}

Variable distance between countries has a negative and significant effect on Indonesian exports with AJCEP member countries and non AJCEP countries. The results of this estimation indicate the negative relationship between Indonesian exports and AJCEP member countries and non-member countries of AJCEP. This shows that the gravity model can explain the flow of Indonesian export trade with AJCEP member countries and non-AJCEP members. Gravity model determines that the farther the distance between one country and its trading partners, the trade level of the two countries will decrease. The farther distance between countries causes the emergence of trading costs such as transportation costs and risks in the delivery period so that the farther the distance of the country that trades, it will cause the costs incurred to increase or increase.

\section{Dummy FTA On Indonesia's Total Exports}

FTA dummy variables show the effect of trade creation or trade diversion on Indonesian exports in member and non-AJCEP countries. Based on previous estimates, the formation of AJCEP creates a greater effect of trade creation than trade diversion. The estimation results are in line with the results of research conducted by Yang and Inmaculada (2014). In his research stated that in the aggregate, the formation of the agreement area creates trade creation, with a note that producers who produce products at low prices. This also agrees with Kien (2010), and Okabe and Urata (2014). A positive coefficient indicates that there is an effect of Indonesia's export trade creation with AJCEP member countries. This means that Indonesia's export goods can replace a portion of domestic goods produced in ASEAN and Japan.

\section{Conclusions}

Based on the results of the estimation of the research described earlier to estimate the effect of trade creation and trade diversion between Indonesia and AJCEP member countries and non-AJCEP members in the period 2000-2015. Based on the results of this study and the discussion in chapter four, the following conclusions are obtained:

1. The total GDP variable has a positive and significant effect on Indonesia's total exports. This shows that with increasing income and output in a country will encourage demand for goods and services. Therefore, an increase in GDP can boost exports.

2. Difference variables or differences in GDP per capita have a negative and significant effect on Indonesia's total exports. This shows that the high difference or difference in income per capita of a country that conducts trade so that when the difference or difference in per capita income of the country of Indonesia with member countries and non-AJCEP members increases or increases it will have an impact on the decline in total Indonesian exports because the higher the difference or the difference in per capita income indicates the lag of a country's economic conditions. So that the Indonesian state will reduce its total exports to AJCEP member countries because it is considered that its goods and services cannot compete, and its quality is deemed unable to meet the qualifications of import destination countries.

3. Exchange rate variables have a positive and significant effect on Indonesia's total exports. This shows that the exchange rate of the partner country has experienced appreciation, and the exchange rate of Indonesia experiences depreciation so that this will make goods relatively more expensive and will increase export demand. 
INTERNATIONAL JOURNAL OF ACADEMIC RESEARCH IN BUSINESS AND SOCIAL SCIENCES

Vol. 10, No. 5, May, 2020, E-ISSN: 2222-6990 @ 2020 HRMARS

4. FTA dummy variables have a positive and significant effect on Indonesia's total exports. This shows that the formation of the ASEAN-JAPAN COMPREHENSIVE ECONOMIC PARTNERSHIP agreement has caused the effect of trade creation on Indonesia's export side towards AJCEP member countries. The impact as a whole can improve welfare for member countries and non-AJCEP members.

\section{References}

Beers, V. C. (2000). Is the gravity model a flawed instrument in measuring economic integration effects. of Economics Journal. 38 (2): 1-10.

Elliott, R. J., \& Ikemoto, K. (2004). AFTA and the Asian Crisis: Help or Hindrance to ASEAN IntraRegional Trade?. Asian Economic Journal, 18(1), 1-23.

Halwani, H. (2005). International Economy and Economic Globalization. Second edition, Jakarta: Ghalia Indonesia.

Haryadi, R. O., Tambunan, M., \& Achsani, N. A. (2008). Impact of Elimination of Agricultural Sector Trade Barriers to Economic Performance in Developing and Developing Countries.

Kien, N. T. (2009). Gravity model by panel data approach: an empirical application with implications for the ASEAN free trade area. ASEAN Economic Bulletin, 26(3), 266-277.

Krueger, A. O. (1999). Trade creation and Trade Diversion under NAFTA. National Bureau of Economic Research, WP 7429.

Krugman dan Obstfed. (2012). International Economics Theory and Policy.9th edition. Boston: Pearson Education.

Lindert, P. H., and Kindleberger, C. P. (1986). International Economics, 8th Edition. Homewood, IL: RD Irwin.

Mankiw, N. G. (2007). Macro Economy Sixth Edition. Erlangga. Jakarta

Okabe, M., \& Urata, S. (2014). The impact of AFTA on Intra-AFTA trade. Journal of Asian Economics, $35,12-31$.

Salvatore Dominick. (1996). Ekonomi Internasional 5th ed. Jakarta: Erlangga.

Starck, C. S. (2012). The theoretical foundation of gravity modeling: What are the developments that have brought gravity modeling into mainstream economics. [tesis]. Denmark: Copenhagen Business School.

Urata, S., \& Kiyota, K. (2003). The impacts of an East Asia FTA on foreign trade in East Asia (No. w10173). National Bureau of Economic Research.

Venables, J., Anthony. (2000). International trade regional economic integration. The International Encyclopedia of Social and Behavioral. 12(2): 233-254.

Yang, S., \& Martinez-Zarzoso, I. (2014). A panel data analysis of trade creation and trade diversion effects: The case of ASEAN-China Free Trade Area. China Economic Review, 29, 138-151. 